\title{
A tool to enhance the planning of children's literature lessons for Setswana as Home Language
}

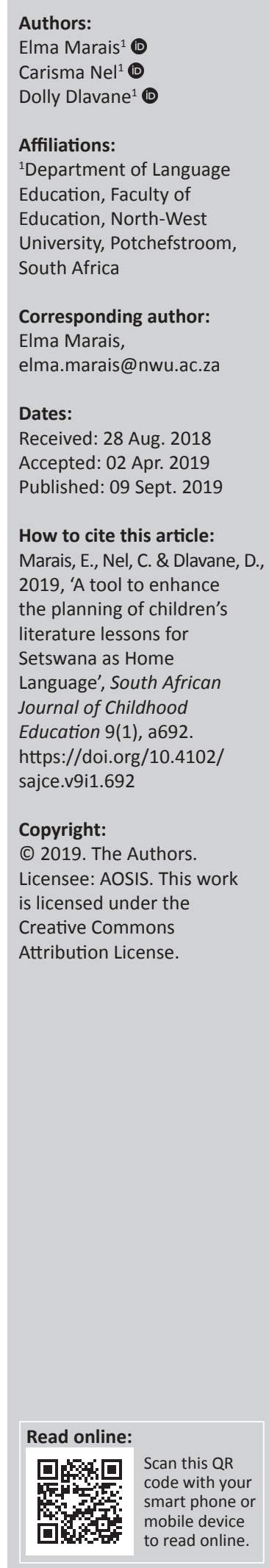

Background: Universities, specifically faculties of education, have the responsibility to ensure that student teachers are introduced to the complexities involved in planning conceptually sound, coherent and cohesive lessons.

Objectives: The objectives of this study were to determine how prepared students teachers are to plan children's literature and develop a tool for use by teachers specializing in Setswana to support them when planning and preparing for children's literature lessons.

Methods: A Qualitative case study design was chosen for this study.

Results: The results of this study indicated that primary pre-service teachers in South Africa do not receive cohesive and coherent as well as intensive preparation in the planning of lessons focusing on children's literature. In addition, most primary pre-service teachers were not familiar with the titles, some genres and levelled questioning techniques used in planning children's literature lessons. The results indicated that student teachers studying at a distance and specialising in Setswana as a Home Language were experiencing difficulties relating to the literature planning and preparation.

Conclusion: Skillful planning, entails taking into account the knowledge and developmental level of learners, their specific social and cultural contexts, knowledge of subject matter and learning goals, as well as knowledge of teaching strategies and practices.

Keywords: Lesson Planning; Setswana; Children's Literature; Evaluation; Genre; Primary School.

\section{Introduction}

Research evidence stating that poor learner performance in schools is because of 'many teachers' lack of understanding of and inability to adequately convey the content knowledge of the subjects they are teaching' is becoming more evident in South Africa (Deacon 2016:3). This research is supported by international consensus that one of the most important variables affecting educational quality is the competence of the teacher (Darling-Hammond 2006). DarlingHammond (2006) proposes that the development of good teachers and exposure to quality teaching should take place at universities offering Initial Teacher Education (ITE) programmes. However, Darling-Hammond acknowledges that the training offered within teacher preparation programmes can vary significantly. The Initial Teacher Education Research Project (ITERP) study findings support this statement, indicating that the content of programmes in South African institutions varies widely (Taylor 2014). Taylor (2014) states that:

Evidence has accumulated over the last two decades to suggest that in-service interventions have had limited impact. This understanding, in turn, has led to a growing realisation that the greatest opportunity for improving the quality of schooling lies in strengthening initial teacher education. (p. 6)

ITE programmes in South Africa are currently facing scrutiny with regard to subject content depth and rigour (i.e. language and mathematics) as well as regarding the work-integrated learning component of the Bachelor of Education (BEd) programme (Nel 2018). Research indicates that courses offered within teacher preparation programmes do not adequately prepare student teachers to plan for effective instruction (Duncan 2010; Maphosa \& Mudzielwana 2014; National Council on Teacher Quality 2010) and support student teachers in their development of the skills to plan and prepare effectively and coherently (Holm \& Horn 2003; Jones, Jones \& Vermette 2011) because a strong relationship exists between teacher planning and learner achievement, and ineffective planning practices learnt in teacher preparation programme modules or courses may manifest once student teachers begin teaching within their own classrooms (Joneset al. 2011).

It is difficult to overstate the importance of planning. Sardo-Brown (1996:519) defines planning as 'the instructional decisions made prior to the execution of plans during teaching'. Danielson 
(2007:27) states 'that a teacher's role is not so much to teach as it is to arrange the learning'. According to Danielson (2007), teachers who excel in planning and preparation:

[D]esign instruction that reflects an understanding of the disciplines they teach - the important concepts and principles within that content, and how the different elements relate to one another and to those in other disciplines. They understand their students - their backgrounds, interests, and skills. Their design is coherent in its approach to topics, includes sound assessment methods, and is appropriate to the range of students in the class. (p. 27)

In research conducted by Chesley and Jordan (2012:43), teachers stated that, 'We didn't know how to plan for instruction'. Findings from the ITERP study also indicate that within the teacher preparation programmes that were reviewed, there was limited information on lesson planning in both the Home Language and First Additional Language methodology course materials. The use of micro-teaching as a practice-based opportunity was also negligible (Reed 2014:27). Student teachers' ability to deliver developmentally appropriate instruction depends on their ability to plan coherent and cohesive lessons. To plan, they will have to learn to sequence their content and align it with appropriate instructional practices relevant to the content being taught. Effective planning also ensures that the needs of all learners are catered for and that differentiation is addressed.

Good planning is crucial if student teachers need to have an impact on the learning of the learners. Although experienced teachers can, perhaps, manage to 'fly by the seat of their pants', they cannot do so for long (Danielson 2007:57). However, there is not much research addressing exactly how student teachers are taught to plan in courses offered within teacher preparation programmes. The aim of this article is, firstly, to report on student teachers' views of their preparedness for teaching children's literature lessons; secondly, to report on how lecturers or their substitutes prepare the student teachers for planning to teach children's literature lessons; and, lastly, to determine how subject advisors support teachers for planning and preparing children's literature lessons. The outcome is to present a tool that can be used as a resource to assist them in their planning and preparation of children's literature.

\section{Conceptual framework}

Shulman's (1987) model of pedagogical reasoning and action steps provides a conceptual framework for this study. The pedagogical reasoning and action steps are processes and practices that can support student teachers as they 'work' from their initial understanding of the content in their subjects to develop pedagogical content knowledge. Shulman (1987) identifies five processes that teacher educators may focus on while scaffolding student teachers' development towards competence in lesson planning and enactment:

1. comprehension

2. transformation

3. instruction

4. evaluation

5. reflection.
According to Shulman (1987:14), the

[V]iew of pedagogical reasoning is from the point of view of the teacher, who is presented with the challenge of taking what he or she already understands and making it ready for effective instruction. (p. 14)

The journey to the development of pedagogical content knowledge growth starts with the importance of the comprehension of content knowledge. To effectively teach the content, student teachers must have mastered the content in breadth and depth. Once they understand the content, they must transform the content knowledge in such a way that it can be taught to learners in a comprehensible manner. During this process, student teachers need to know their learners (i.e. cultural assets, diverse needs and interests, developmental levels, etc. ) to deliver their lessons at the correct level and make instructional adaptations where required. Pedagogical content knowledge is also about recognising what specific learning activities and pedagogy work for the type of content and skills being taught in the lesson (Mishra \& Koehller 2006). Transforming knowledge into a learner-friendly format is essential for pedagogical practice. Instruction is the enactment process and includes many pedagogical aspects such as managing the classroom, providing clear explanations and examples, and focussing on the gradual release of responsibility in the learning process (McVee et al. 2015). Evaluation focuses on student teachers' checking of learner understanding. Reflection should allow student teachers and in-service teachers to reflect on what was successful, what can be improved, more efficient methods of materials, classroom and content management, etc. (Shulman1987).

\section{Planning children's literature lessons}

Children's literature should be an essential component of every primary school curriculum and should not merely be included at the whim of the teacher or just to pass time (Cremin et al. 2008; Hancock 2000; Leu et al. 2003; Stan 2015; Waugh, Neau \& Waugh 2016). The existing Curriculum and Assessment Policy Statements for the Foundation Phase and the Intermediate Phase allow for instructional time, specifically for the integration of children's literature into the daily or weekly timetable, and indicate a range of stories as well as information and graphical text (Department of Basic Education 2011). Teachers' competency should include the ability to enhance learners' reading choices, habits and positive attitudes. In addition, their competence should include knowledge of authors, titles, genres and the variety of texts available for children (Akins et al. 2018; Cremin et al. 2008; Cunningham et al. 2004). Research indicates that teachers need to read widely and be familiar with a variety of book titles and genres in order to support the reading development of young children, and this should include the reading of specifically children's literature (Collins \& Safford 2008; Cremin et al. 2008; Ripp 2016). In her study, Marais (2014) indicates that teachers responsible for Afrikaans as Home Language and First Additional Language from grades 1 to 6 and subject advisors were unable to identify 
titles, genres, narrative elements as well as recommend developmentally appropriate texts to learners in the identified grade levels. Marais (2014) also found that teachers' knowledge of children's literature was limited to their knowledge of their own childhood favourites. In addition, Akin et al. (2018) pointed out that there is a gap regarding the genres that teachers know specifically with regard to multicultural and historical fiction. McCutchen et al. (2002:210) state that, 'If teachers are to create and maintain a literate environment for their students, we might expect teachers to be knowledgeable about children's literature'.

The research seems to indicate that ITE programmes are neglecting the inclusion of children's literature within the curriculum. Within the South African context, this statement is supported by results from the ITERP (Deacon 2016; Reed 2014). According to Reed (2014), children's literature is given limited attention at the institutions that were part of the ITERP study. Reed (2014:27) states that, 'This situation is a cause for concern given the importance of developing learners' interest in reading'. Research seems to indicate the importance of the inclusion of topics focussed on encouraging reading widely, knowledge of children's books, when and how to use texts, recommending books to learners appropriate to their language, social, personality and cognitive developmental levels (cf. Marais 2014).

\section{Methodology}

The following research questions were formulated for this study:

- How prepared are student teachers to plan and prepare for teaching children's literature lessons?

- How do lecturers or their substitutes prepare student teachers for planning and preparing to teach children's literature lessons, specifically related to:

- lesson format

- familiarity with genres in children's literature, narrative elements and criteria for choosing developmentally appropriate children's literature.

- How do subject advisors support teachers for the planning and preparation of children's literature lessons?

\section{Research design}

A qualitative case study research design was chosen for this study because the aim was to address 'how' related to preparedness of children's literature planning and preparation, student teachers', lecturers or their substitutes as well as subject advisors' (Yin 2009:1). One teacher preparation programme formed the bounded context of this study.

\section{Sampling}

Non-probability sampling was used to collect information from participants identified to participate in this study, and which ensures that data collected are not biased or skewed (Cohen, Manion \& Morrison 2007). Purposeful sampling was utilised in choosing participants based on the needs of the research and the requirements related to participants' 'typicality and possession of a particular characteristic being sought' (Cohen et al. 2007:114-115). A total number of eight lecturers teaching Setswana, English and Afrikaans as Home Language, and English and Afrikaans as First Additional Language $(N=8)$, or substitutes participated in this study. Two language subject advisors from a school district in close proximity to the university also participated in the study. Student teachers in year $1(N=60)$, year $2(N=45)$, year 3 $(N=25)$ and year $4(N=15)$ of the BEd Foundation Phase and Intermediate Phase programme participated in the study. A total of $78 \%(N=113)$ of the participating student teachers were enrolled in the BEd programme offered at a distance; the remaining $22 \%(N=32)$ were on campus student teachers. The student teachers specialised in English, Setswana or Afrikaans as Home Language. The students enrolled for the BEd degree are situated across all provinces of South Africa.

\section{Data collection methods}

In this study, four data collection methods were used, namely, focus group interviews, semi-structured interviews, an analysis of WhatsApp messages and document analysis. A focus group interview was held with the language lecturers and the substitutes to determine how they prepare the student teachers for planning and preparing to teach children's literature lessons, specifically related to format of lessons and familiarity with genres in children's literature, narrative elements and criteria for choosing developmentally appropriate children's literature.

Two focus group interviews were also held with first, second, third and fourth year full-time on-campus students to determine their preparedness to plan and prepare for teaching children's literature lessons.

Semi-structured interviews were held with the two language subject advisors in order to ascertain their points of view and perceptions related to teachers' preparedness to teach children's literature in the Foundation Phase and Intermediate Phase.

In this study, WhatsApp messages were analysed and interpreted by the researchers to give voice and meaning to the distance students' points of view in terms of their preparedness to plan and prepare children's literature lessons.

Document analysis of $N=45$ lessons plans was made to corroborate the focus group interviews, the semi-structured interviews and the WhatsApp messages.

\section{Methods of analysis}

Data were analysed using qualitative content analysis. Seven steps were followed in the analysis procedure, firstly, prepare the data (all data were transformed into written text and choices were made in terms of what to transcribe and what not to transcribe - non-verbal communication was not transcribed); secondly, define the unit of analysis (themes were used as the unit of analysis in this study); thirdly, develop categories and a coding scheme (open, axial and 
selective codings were utilised); fourthly, test your coding scheme on a sample of text (sample text was coded and consistency and accuracy were checked by a qualitative research specialist); fifthly, code all the text (coding was controlled and checked repeatedly); sixthly, assess your coding consistency (consistency of the coding was checked to ensure that errors and fatigue did not play a role); and seventhly, draw conclusions from the coded data (the focus here is on sense-making of the identified themes and uncovered patterns) (De Wever et al. 2006; Henning, Van Rensburg \& Smith 2004; Miles \& Huberman 1994; Patton 2002; Schilling 2006; Thietart 2007; Weber 1990).

\section{Ethical considerations}

Ethical clearance was obtained for the project via the research ethics committee at the university where the study was conducted (Ethical clearance number: NWU-00344-17-A2).

\section{Results and discussion}

The focus group interviews held with the lecturers and substitutes responsible for teaching literacy and language within the Foundation Phase and the Intermediate Phase indicated that they made reference to planning lessons in the methods module. However, none of the lecturers indicated that they gave detailed attention to lesson planning, specifically the planning of lessons where children's literature was a focus. The English First Additional Language lecturers in the Intermediate Phase indicated that they support their full-time students with lesson planning.

We don't have time. Our focus is on the content knowledge that these students must get. (Lecturer 1, female, age 54)

We do lesson planning, but it is not done in depth. (Lecturer, female, age 38)

When they go out for teaching practice, we just let them plan the way they want or use the planning method of the mentor teacher. (Lecturer 1 and 2, female age 54 and age 38)

I just have to check that they did include their lesson plans in their portfolios. I don't have to assess it per se. (Lecturer 3, female, age 52)

During the methodology periods for the full-time students, my focus is on teaching the strategies and methods they can use when teaching children's literature lessons. (Lecturer 4, female, age 44)

The whiteboard sessions for the distance students cover the essential content they need for exam preparation - we do not do lesson planning at all. (Lecturer 5, female, age 47)

I don't think planning is really done in a coherent way in any module - I guess we assume they can do it. We just tell them the main things that are the goal, the methods and strategies to include, the activities and so on. (Lecturer 6, female, age 45)

The lecturers and the substitutes indicated that the university frowned upon the prescribing of too many texts. They also mentioned that they do not require the student teachers to buy or read children's literature. One lecturer sends her fulltime contact student teachers to the library to take out children's literature and also includes an assignment in which they have to justify their choice of text related to a specific grade level (i.e. readability) and they also have to write their own historic literature texts for use in the classroom.

Students are not familiar with children's literature. They can give you the titles of the very traditional stories such as Little Red Riding Hood, The Three Little Pigs, and so on. These are usually the texts that they read as children or that were read to them.

They even do this in Setswana - they give me the titles in English.

The distance students are not required to read any children's literature.

I have to adapt the distance students' assignment because I can't send them to the library to take out books and read. (Lecturer 4, female, age 44)

When asked whether the student teachers were taught to ask different types of questions when focussing on children's literature, the lecturers responded that 'this should be taught by the general education lecturers - curriculum studies'. The Setswana lecturers also indicated that the student teachers were familiar with the following narrative elements, characters, theme or plot and setting:

During teaching practice, they only do character, plot and setting. They say that is all the mentor teachers require them to do. They have to stick to the departmental workbooks, because the subject advisors check up on them [the teachers].

It is so difficult to just get Setswana texts that to introduce the student teachers to things like vocaliser and narrator or even the importance of illustrations is just too much.

We have changed the coursework to now include a lot more children's literature, but we do not focus on teaching them about planning - they do that during teaching practice. (Lecturer 1 , female, age 54)

The semi-structured interviews with the subject advisors indicated that they advised teachers to make use of the departmental workbooks because the schools cannot afford to buy children's literature because it is expensive. They also mentioned that there were not many texts available in Setswana. When asked about what types of genres they wanted the teachers to include in the lessons, they answered 'lots of culturally relevant stories'. The subject advisors were not able to give examples of five children's literature titles (only the traditional English titles such as Goldilocks and the Three Bears, etc.) and they considered the focus on 'illustrations' to be a means of accessing the meaning of the story or to 'guess' the vocabulary. One subject advisor mentioned that within the workbooks stories are included but stated that because the teachers do not choose these stories themselves, they do not always know what is important for learners to know. She stated:

[T]hey've got nothing to read you know and uhm I, I, I try to explain to them you need to build up a variety of books of different levels so that you build up a graded system so children can come in and take a book that they feel comfortable with and then later they take a more challenging book you know. That's what I'm trying to and also that they can use authentic reading material you know they can use stories from magazines and they can use a cereal box actually or a Simba chips packet you know 
but they mustn't tell me that there's nothing to read ... (Subject advisor 1 , female, age 56)

When asked about the importance of lesson planning, the subject advisors indicated that they were only interested in the files of the teachers. The focus was on the inclusion of the correct documents being included in specific files. The planning should include dates, week numbers and the specific topic that forms the focus of a lesson or what is done during day programmes within Grade R:

The teachers must put the things in the files in the way that we tell them to. (Subject advisor 2, female, age 54)

The teachers must do weekly plans and show what they do when. (Subject advisor 2, female, age 54)

The focus group interviews with the contact student teachers and the analysis of distance students' WhatsApp messages indicated that they were fairly familiar with some narrative elements:

When we prepare our lessons we focus on the characters, plot and setting. That is what the teachers did when we were at school and if we ask the learners questions on these things, the lecturers and our mentor teachers seem to be satisfied. (Student teacher 1 , female, age 22)

The lecturers tell us to make sure we 'hook' the learners with good introductions. (Student teacher 3, female, age 28)

I don't talk about illustrations. (Student teacher 4, female, age 21)

I will not be able to tell the children what types of books to read or even give them some guidance on titles. (Student teacher 5, female, age 58)

At the school where I was they had a Diskonto Book Sale and the Setswana learners chose sticker books or books in English. (Student teacher 6, female, age 24)

With regard to planning their lessons, all the distance student teachers commented on how difficult it was and that they were not sure what was required of them. These comments were similar for student teachers from year 1 to year 4 :

I don't know what I should write under Learners background knowledge - I just wrote that if the book is about snow and I know the learners in the township won't know this, I will explain it. (Student teacher 4, female, age 21)

Do I just get the learning objectives from the CAPS document? (Student teacher 7 , female, age 20)

I don't know what the lecturers want when the template asks for the procedure when planning - I just tell what I will do and what the learners must do. I tell them about the worksheets I will use and what questions I will ask the learners - like you know; Who is the main character in the story? Where does the story take place? Was the boy happy or sad? (Student teacher 8, female, age 33)

I know - sort of - what to do for English, but in doing my Setswana lessons I am a bit lost. (Student teacher 2, female, age 25)

The information on planning we get is either in English or Afrikaans, but we battle in Setswana. (Student teacher 9, female, age 30)

I do not know how to plan for a literature lesson te; what does the lecturer want - Eish, the teachers at school tell us they just say we are doing a story in the workbook. (Student teacher 10, female, age 23)
In this one module they tell us about planning, but it is general stuff and the lecturer can't help us with the language content we must plan - we suck it out of our thumb. (Student teacher 11, female, age 21)

The student teachers struggled to indicate what features a 'good' book has and what criteria they need to use when choosing a book. It is clear that the student teachers do not have enough knowledge to make informed decisions on good children's literature and the value that children's literature could add to the classroom. It was also evident that the student teachers struggled to plan lessons using children's literature - the lesson plans focussed mainly on naming and describing the main characters and linking this to a language element (e.g. tenses). From the research conducted it is evident that the student teachers are not familiar with the different genres and sub-genres within children's literature. Student teachers are uncertain about the classifications of children's literature and the value that each genre has for the development of a child:

I don't know any historical literature - maybe it is something with Tata Mandela? (Student teacher 12, female, age 34)

I just know Itumeleng A Tla A Thusa and Noga - I saw these at a school. They are stories. (Student teacher 13, female, age 29)

The lecturers do not tell us about different stories in Setswana. (Student teacher 14, female, age 33)

An analysis of the student teachers' lesson plans indicated that different aspects such as lesson aims, resource materials (e.g. literacy or language workbooks), learner activities and assessments were addressed. The analysis corroborated the statements made by all the participants. Planning only referred to the book that was chosen for discussion (e.g. Re a tshameka, The Three Little Bears); the questions that the student teachers asked were at the lowest cognitive level; across grade levels, there was no variety in the genres chosen. The students also focussed on the most common aspects of the stories such as character, plot and setting. There was very little evidence about active engagement of the learners or about developmentally appropriate choices for texts.

Planning and preparation involve more than simply writing down on a piece of paper what should be done for the day, or during the week. Planning includes various aspects such as in-depth knowledge of learners, the availability of various resources, including technology resources, knowledge of content, knowing how to select learning goals, choice of learning activities, strategies and practices as well as planning for assessment. The research results clearly indicate that planning is 'not something that most people know how to do intuitively or that they learn from unguided classroom practice' (Darling-Hammond et al. 2005:176). It seems as if the teacher preparation received by these student teachers has promoted a simplistic conception of lesson planning as discrete components needed to be considered without any coherence. These findings are similar to those found by Rusznak and Walton (2011) related to students' 
lesson planning. The results clearly indicate that lesson planning is not done in a coherent, cohesive and subjectspecific manner within this training programme. In addition, the comments made by the student teachers studying at a distance indicate that they are at a disadvantage concerning the preparation and exposure they receive with regard to lesson planning and also children's literature in general.

The results also indicate that the Peter effect (Applegate \& Applegate 2004) is relevant to this study as one cannot be expected to find what one does not possess. The student teachers cannot be expected to plan and prepare children's literature effectively if their 'role models' are not modelling effective practice.

\section{A tool for use when planning and preparing Setswana children's literature lessons}

A tool was developed for use by pre-service student teachers; however, the tool can also be used by in-service teachers and lecturers who specialise in Setswana as Home Language. The tool includes information related to different genres, the most important attributes of the genre, the aim of the genre and the different types. In addition, narrative elements, as well as possible questions that student teachers may consider including when planning and discussing the selected genre, are included. An attempt has been made to display the most important information in a user-friendly manner and to use the layout of a wheel where the segments indicate the differences between the various types of genres as well as the narrative elements (see Figure 1 and Figure 2).

The tool has been developed by the first author, and the third author was responsible for checking the accuracy and relevance of the information for Setswana pre-service student teachers. The tool is available electronically as well as in hard copy to ensure that student teachers' preferences as well as accessibility to and familiarity with electronic devices were taken into consideration.

In Figure 1, on side 1, the genres, the main characteristics, the purpose (i.e. narrative elements prominent in specific genre), the types (i.e. sub-genres) as well as the way in which the genres may be evaluated are illustrated. Side 1 can be turned by a spinning action to show only one segment at a time so that student teachers can easily see the information relevant to the specific genre that is to be the focus of the lesson. Side 1 is divided into seven segments, with each segment focussing on a specific genre. For the sake of completeness, a decision was made to include all genres, even though all the genres are not necessarily addressed in all phases of the Curriculum and Assessment Policy Statement (CAPS) curriculum. The seven segments are picture books, traditional literature, fantasy, reality literature, historical literature, biographies and drama. Each segment is divided into five parts, namely, recommend teaching phase, characteristics, purpose, evaluation and narrative elements, and types or

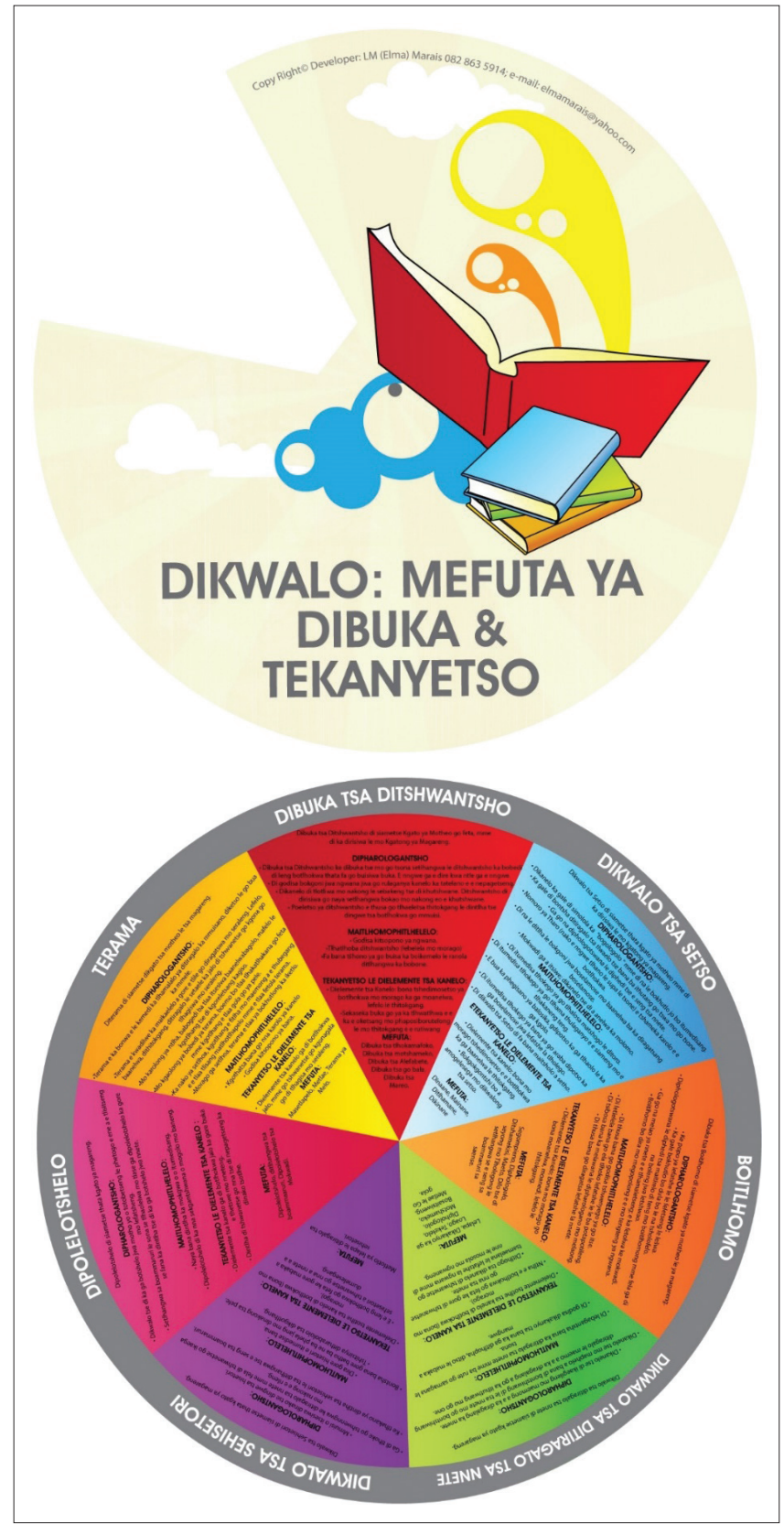

FIGURE 1: Genres.

sub-genres. The parts, therefore, indicate which phase the type of genre is most suitable for. The characteristics of the particular genre are then indicated, as in the case of picture books where the illustrations are an essential part of the book, or a picture book may even have no text at all. The purpose of the genre is mentioned, as well as the reasons why teachers would use the particular type of genre. It is further indicated what the most important elements are that should be examined when the type of genre is evaluated, and, lastly, the sub-genres of the specific category are pointed out. This tool does not aim to be the only source of information, but may serve as a quick guide to assist student teachers with their planning of children's literature lessons when no resources are available while they are on teaching practice. In addition, the purpose was to ensure that when student teachers plan their lessons while on teaching practice they 


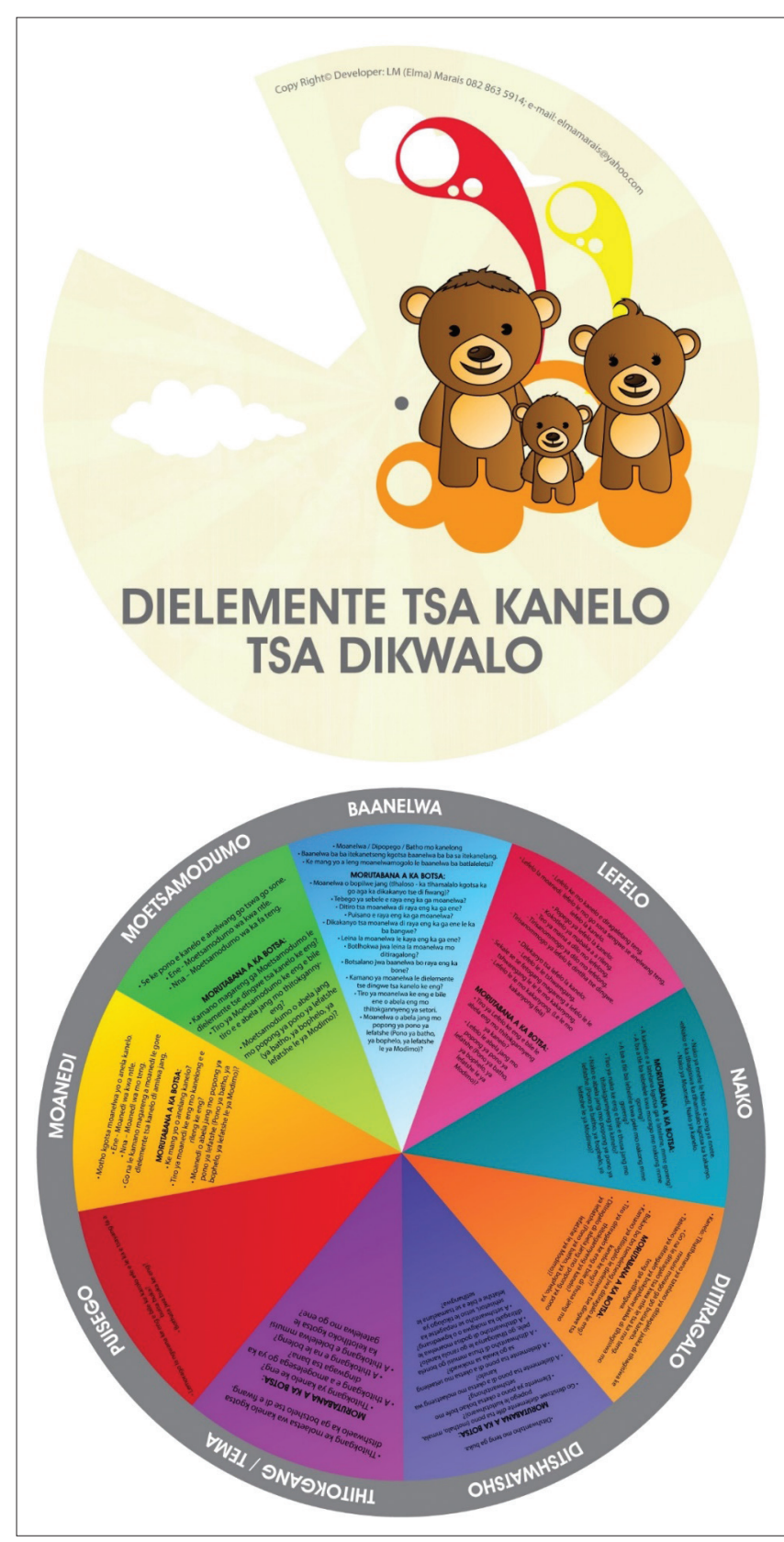

FIGURE 2: Narrative elements.

had access to a user-friendly tool that could at the very least ensure that content knowledge planning was accurate and that important concepts were addressed during the enactment of the lesson.

In Figure 2, the narrative elements are highlighted for the student teacher. Side 2 is divided into nine segments. Each segment explains a specific narrative element that is important in children's literature. For the sake of completeness, a decision has been made to include all the elements as well as how illustrations can play a role. The nine segments are readability, narrator, vocaliser, characterisation, setting, time, events, illustrations and theme or topic. Each segment is divided into two parts, namely, features and teacher can ask. The features include a brief outline of what each element entails and how it may affect the story.
The second part, 'teacher can ask', relates to the different types of questions the student teachers can ask regarding the specific element. For example, if the focus is on the narrator, the student teachers may ask: 'Who is telling the story?'

\section{Conclusion}

Universities, and specifically faculties of education, have a responsibility to prepare student teachers so that they can enter the profession with the knowledge, skills and dispositions needed to successfully teach children in a developmentally appropriate manner. Student teachers must be able to plan and deliver instruction to all learners in order to ensure success for all learners. The inclusion of children's literature in ITE programmes is a significant problem, and the support that student teachers need in order to ensure that their impact on learners is successful will necessitate a far greater commitment to quality teacher preparation than what is currently the case.

Student teachers and in-service teachers who have difficulty in locating appropriate text may consider the following websites:

- https://digitallibrary.io/

- https://storyweaver.org.in/

- http://www.africanstorybook.org/

- http://www.worldreader.org/what-we-do/worldreadermobile/

Student teachers require practice-based opportunities during their training to ensure that they develop the competences necessary to plan effective lessons. They also need to receive effective feedback to ensure professional growth. The preparation and support provided to student teachers studying at a distance, and also specifically student teachers studying African languages, in the case of this study Setswana - requires attention. Planning per se and the planning of children's literature occur via osmosis; however, it occurs when instruction on planning is part of a structured programme (i.e. learning from and in practice). Teacher preparation programmes must assume responsibility for ensuring that pre-service teachers are ready to enter the profession so that they can implement responsible practice.

\section{Acknowledgements}

The authors would like to thank the reviewers for the helpful suggestion on the first draft of this article.

\section{Competing interests}

The authors declare that they have no financial or personal relationships that may have inappropriately influenced them in writing this article.

\section{Authors' contributions}

E.M. conceptualised the development and design of the planning tool. C.N. conceptualised the research project, 
performed the literature review, identified the research methodology and initiated the writing up of the article.

D.D. edited the Setswana tools for language and content accuracy.

\section{Funding information}

The European Union via PrimTEd project provided funding for this research.

\section{Data availability statement}

Data sharing is not applicable to this article as no new data were created or analysed in this study.

\section{Disclaimer}

This publication has been developed through the Teaching and Learning Development Capacity Improvement Programme, which is being implemented through a partnership between the Department of Higher Education and Training and the European Union. The opinions expressed are those of the authors and should not be attributed to the Department of Higher Education and Training or the European Union.

\section{References}

Akins, M., Tichenor, M., Heins, E. \& Piechura, K., 2018, 'Teachers' knowledge of children's literature: What genres do teachers read?' Reading Improvement 55(2), 6368.

Applegate, A.J. \& Applegate, M.D. 2004, 'The Peter effect: Reading habits and attitudes of teacher candidates', The Reading Teacher 57(6), 554-563.

Chesley, G.M. \& Jordan, J., 2012, 'What's missing: Teacher prep', Educational Leadership 69(8), 41-45.

Cohen, L., Manion, L. \& Morrison, K., 2007, Research methods in education, 6th edn., Routledge, London.

Collins, F.M. \& Safford K., 2008, 'The right book for the right child at the right time: Primary teacher knowledge of children's literature', Changing English 15(4), 415-422. https://doi.org/10.1080/13586840802493068

Cremin, T., Mottram, M., Bearne, E. \& Goodwin, P., 2008, 'Exploring teachers knowledge of children's literature', Cambridge Journal of Education 38(4), 449-464. https:// doi.org/10.1080/03057640802482363

Cunningham, A.E., Perry, K.E., Stanovich, K.E. \& Stanovich, P.J., 2004, 'Disciplinary knowledge of K-3 teachers and their knowledge calibration in the domain of early literacy', Annals of Dyslexia 54(1), 139-167. https://doi.org/10.1007/s11881-004$0007-y$

Danielson, C., 2007, Enhancing professional practice. A framework for teaching, Association for Supervision and Curriculum Development (ASCD), Alexandria, VA

Darling-Hammond, L., 2006, 'Constructing 21st-century teacher education', Journa of Teacher Education 300(57), 300-314. https://doi.org/10.1177/002248710 5285962

Darling-Hammond, L., Banks, J., Zumwalt, K., Gomez, L., Sherin, M.G., Griesdorn, J. et al., 2005, 'Educational goals and purposes: Developing a curricular vision for teaching', in L. Darling-Hammond \& J. Bransford (eds.), Preparing teachers for a changing world: What teachers should learn and be able to do, pp. 169-200, Jossey-Bass, San Francisco, CA.

Department of Basic Education, 2011, Curriculum and Assessment Policy Statement. Grades 4-6, Government Printers, Pretoria.

De Wever, B., Schellens, T., Valcke, M. \& Van Keer, H, 2006, 'Content analysis schemes to analyze transcripts of online asynchronous discussion groups: a review', Computer \& Education 46(1), 6-28. https://doi.org/10.1016/j.compedu.2005.04.005

Deacon, R., 2016, 'The initial teacher education research project: Final report', JET Education Services, Johannesburg.
Duncan, A., 2010, 'Teacher preparation: Reforming the uncertain profession', Education Digest 75(5), 13-22.

Hancock, M., 2000, A celebration of literature and response, Pearson, Boston, MA.

Henning, E., Van Rensburg, W.V.Q. \& Smith, B., 2004, Finding your way in qualitative research, Van Schaik, Pretoria.

Holm, L. \& Horn, C., 2003, 'Bridging the gap between schools of education and the needs of 21st-century teachers', The Phi Delta Kappan 84(5), 376-380. https:// doi.org/10.1177/003172170308400511

Jones, K.A., Jones, J. \& Vermette, P.J., 2011, 'Six common lesson planning pitfallsrecommendations for novice educators', Education 131(4), 845-864.

Leu, D.J., Kinzer, C.K., Coiro, J. \& Cammack, D.W., 2003, 'Toward a theory of new literacies emerging from the Internet and other information and communication technologies (ICT)', in R. Ruddell \& N. Unrau (eds.), Theoretical models and processes of reading, 5th edn., International Reading Association, Newark, DE.

Maphosa, C. \& Mudzielwana, N., 2014, 'Trainee teachers' experiences of being observed teaching while on teaching practice: A case of BEd Foundation Phase students in one rural university', Mediterranean Journal of Social Sciences 5(16), 393-402. https://doi.org/10.5901/mjss.2014.v5n16p393

Marais, L.M., 2014, "n Professioneleontwikkelingsprogram vir die integrasie van kinder- en jeugliteratuur in die Afrikaanse skoolkurrikulum [A professional development program for the integration of children's and youth literature into the Afrikaans school curriculum]', PhD thesis, Faculty of Education, North-West University.

McCutchen, D., Harry, D.R., Cunningham, A.E., Cox, S., Sidman, S. \& Covill, A.E., 2002, 'Reading teachers' knowledge of children's literature and English phonology', Annals of Dyslexia 52(1), 207-228. https://doi.org/10.1007/s11881-002-0013-x

McVee, M., Shanaham, L., Pearson, P.D. \& Rinker, T., 2015. 'Using the gradual release of responsibility model to support video reflection with preservice and inservice teachers', in E. Ortlieb, M. B. McVee \& LE. Shanahan (eds.), Video reflection in literacy teacher education and development: Lessons from research and practice, pp. 59-80, Emerald Group Publishing, Bingley.

Miles, M.B. \& Huberman, A.M., 1994, Qualitative data analysis: An expanded sourcebook, Sage, Thousand Oaks, CA.

National Council on Teacher Quality, 2010, Transforming teacher education through clinical practice: A national strategy to prepare effective teachers, National Council for Accreditation of Teacher Education, Washington, DC.

Mishra, P. \& Koehler, M.J., 2006, 'Technical pedagogical content knowledge: A framework for teacher knowledge', Teachers College Record 108(6), 1017-1054. https://doi.org/10.1111/j.1467-9620.2006.00684.x

$\mathrm{Nel}, \mathrm{C} ., 2018$, 'Turning teacher preparation programmes upside down: A focus on work integrated learning', paper presented at the AROS conference, Pretoria, 25 July 2018.

Patton, M.Q., 2002, Finding your way in qualitative research, Sage, Thousand Oaks, CA.

Reed, Y., 2014, Initial teacher education research project: Report on English courses for intermediate phase student teachers at five universities, JET Education Services, Johannesburg.
Johne

Ripp, P., 2016, Passionate learners. How to engage and empower your students, Routledge, New York, NY.

Rusznak, L. \& Walton, E., 2011, 'Lesson planning guidelines for student teachers: A scaffold for the development of pedagogical content knowledge', Education as Change 15(2), 271-285.

Sardo-Brown, D., 1996, 'A longitudinal study of novice secondary teachers' planning Year two', Teaching and Teacher Education 12(5), 519-530. https://doi. org/10.4324/9781315689326

Schilling, J., 2006, 'On the pragmatics of qualitative assessment: Designing the process for content analysis', European Journal of Psychological Assessment 22(1), 28-37. https://doi.org/10.1027/1015-5759.22.1.28

Shulman, L.S., 1987, 'Knowledge and teaching: Foundations of the new reform', Harvard Educational Research 57(1), 1-22. https://doi.org/10.17763/ haer.57.1.j463w79r56455411

Stan, R.V., 2015, 'The importance of literature in primary school pupils' development and personal growth', Procedia Social and Behavioural Sciences 180, 454-459. https://doi.org/10.1016/j.sbspro.2015.02.144

Taylor, N., 2014, Initial teacher education research project: An examination of aspects of initial teacher education curricula at five higher education institutions, Summary Report, JET Education Services, Johannesburg.

Thietart, R.A., 2007, Doing management research - A comprehensive guide, Sage, London.

Waugh, D., Neau, S. \& Waugh, R., 2016, Children's literature in primary schools, Sage, Exeter.

Weber, R.P., 1990, Basic content analysis, Sage, Newbury Park, CA.

Yin, R.K., 2009, Case study research: Design and methods, 5th edn., Sage, Thousand Oaks, CA. 